\section{AMINOMETRADINE IN TREATMENT OF CONGESTIVE HEART FAILURE}

BY

M. M. PLATTS, M.B., B.Sc., M.R.C.P. J. G. Graves Research Fellow

AND

\section{T. HANLEY, M.D., M.R.C.P.} Lecturer

Department of Medicine, Sheffield University

Aminometradine, sold under the proprietary name of "mictine," has the chemical formula 1-allyl-3-ethyl-6aminouracil, and is one of a series of substituted aminouracils synthesized by Papesch and Schroeder (1951). Imburgia (1952) administered this substance to eight patients with congestive heart failure and observed a satisfactory diuresis in six of these. Kattus et al. (1952) and Spencer and Lloyd-Thomas (1953) also obtained a successful therapeutic result from two very similar compounds, "SC 2614" and "SC 3088," and found that, apart from causing mild gastro-intestinal upset, these substances were well tolerated and of low toxicity.

The present paper deals with the effect of aminometradine on the urine flow and excretion of electrolytes, and the diuretic effect of this drug on a group of patients with congestive heart failure:

\section{Methods}

The effect of aminometradine on the urine flow and electrolyte excretion was studied on 20 patients with congestive heart failure and on 2 patients with heart disease but without oedema, all of whom ingested a constant amount of fluid $(1,000-1,500 \mathrm{ml}$.) and salt $(0.5$ to $5 \mathrm{~g}$.) daily. They were weighed each day and all urine was collected over periods of 24 hours. The volume and electrolyte content of the urine were measured during a "control" period, which varied from one to seven days in different patients, and the mean values of this period were used for calculation of the changes caused by aminometradine. If a spontaneous diuresis occurred during the control period aminometradine was withheld until the patient's weight became steady. The great majority of patients then received $400 \mathrm{mg}$. of aminometradine daily at the beginning of a urine-collection period. If this did not cause a satisfactory diuresis the dose was increased to $800 \mathrm{mg}$., and, if the

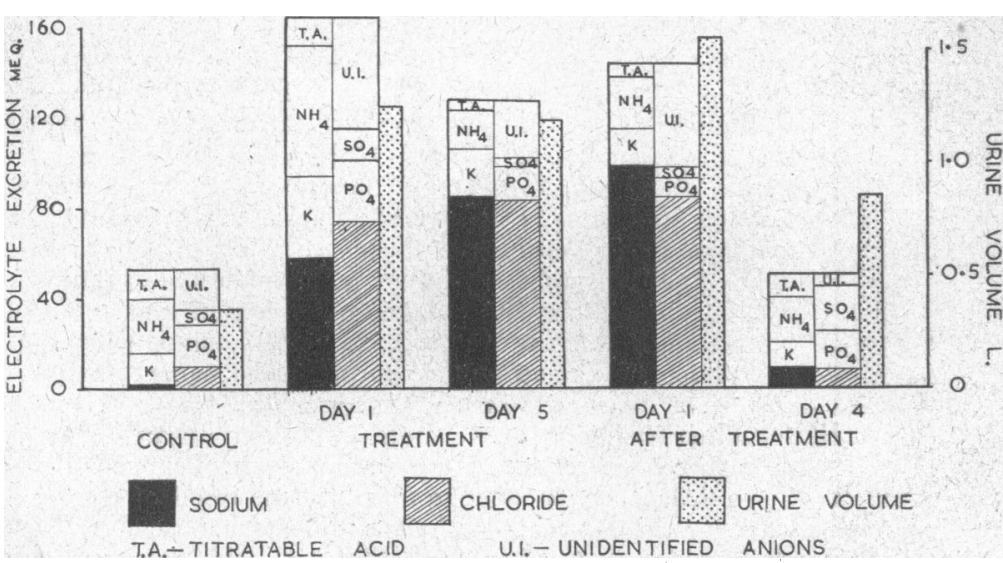

FIg. 1.-Histograms of the daily acid-ba se composition of the urine of a patient with heart failure, before, during, and af ter treatment .with aminometradine (400 with heart failure, before, during, and af ter treatment
$\mathrm{mg}$. daily for five days). response was still poor, then aminometradine therapy ceased and mersalyl injections were given $(2 \mathrm{ml}$. intramuscularly, not preceded by ammonium chloride). The period of treatment ranged from 2 to 11 days, and in many instances the urine measurements continued for several days after the last dose had been given. Two patients with congestive heart failure received alternate doses of aminometradine and mersalyl, one day without any treatment being allowed after each diuretic.

The analytical methods employed have been described in a previous publication (Hanley and Platts, 1956).

\section{Results}

The chief alteration in the acid-base composition of the urine caused by aminometradine consisted of an increased excretion of sodium and chloride ions. The urinary excretion of potassium also almost invariably rose, but to a much less extent than sodium, and there were also small variable changes in the excretion of phosphate, sulphate, ammonia, and titratable acid. In every instance the urine remained acid throughout administration of the drug, and excretion of bicarbonate was negligible. Fig. 1 shows details of these changes in a representative patient with heart failure.

The Table shows the cumulative loss of body weight during the entire period of treatment with aminometradine and the alterations in urinary electrolyte excretion (calculated as changes with respect to the mean pre-treatment rates) which occurred on the day of maximum effect from the drug. The greatest diuresis was not usually observed until the second to fourth day of treatment, and occurred on the first day in only 5 of the 18 patients. The maximum daily changes in sodium excretion ranged from +362 to $-37 \mathrm{mEq}$, and there were corresponding increases of urine flow ranging from 3.16 to $0.13 \mathrm{l}$, with an average of $1.45 \mathrm{l}$. There was a fairly close relation between the increase of urine flow and the elevation of sodium excretion.

Eight patients (Cases 1-8, see Table) had a wholly satisfactory therapeutic effect from aminometradine; they lost from 3.4 to $7.2 \mathrm{~kg}$. of body weight, showed a cumulative increase of urine flow ranging from 1.2 to $12.3 \mathrm{l}$. (average 6.0 1.), and became completely free from oedema, with a corresponding clinical improvement.

Five patients (Cases 9-13) were materially benefited by the drug, but at the end of four to seven days' treatment they were still slightly oedematous, although they had lost from 1.7 to $4.5 \mathrm{~kg}$. of body weight. The remaining five patients (Cases 14-18) had a poor or negligible therapeutic response; the loss of weight was small and ranged from 0.5 to $1.3 \mathrm{~kg}$. in four instances, while the fifth (Case 18) gained weight during treatment and his clinical state grew worse.

Increasing the dose of aminometradine to $800 \mathrm{mg}$. in seven patients who had shown a poor response to $400 \mathrm{mg}$. daily caused a material increase of water and salt excretion in only one person.

Mersalyl was subsequently administered to 8 of these 10 patients who had had only a fair or poor diuresis after aminometradine ; all had a good therapeutic response and became free from oedema after several intramuscular injections of mersalyl, which greatly augmented the excretion of sodium above the level attained during aminometradine therapy. The diuretic effect of mersalyl was also compared with that of aminometradine in five other patients (including Cases 1 and 2 , see Table), who had had a good effect from aminometradine. On the average a slightly larger diuresis and a greater increase of salt excretion again resulted from the mercurial diuretic.

Fig. 2 shows the maximum daily excretion of water and electrolytes produced by aminometradine and mersalyl respectively 
Therapeutic Effect of Aminometradine on Patients with Congestive Cardiac Failure

\begin{tabular}{|c|c|c|c|c|c|c|c|c|c|c|c|c|}
\hline \multirow{2}{*}{$\begin{array}{l}\text { Case } \\
\text { No. }\end{array}$} & \multirow{2}{*}{\multicolumn{2}{|c|}{$\begin{array}{c}\text { Sex } \\
\text { and Age }\end{array}$}} & \multirow{2}{*}{$\begin{array}{c}\text { Cause of } \\
\text { Heart } \\
\text { Failure }\end{array}$} & \multirow{2}{*}{$\begin{array}{c}\text { Daily } \\
\text { Dose of } \\
\text { Amino- } \\
\text { metradine } \\
\text { (mg.) }\end{array}$} & \multirow{2}{*}{$\begin{array}{c}\text { Duration } \\
\text { of } \\
\text { Treatment } \\
\text { (Days) }\end{array}$} & \multirow{2}{*}{$\begin{array}{c}\text { Total } \\
\text { Loss of } \\
\text { Weight } \\
\text { (Kg.) }\end{array}$} & \multirow{2}{*}{$\begin{array}{l}\text { Day of } \\
\text { Maximum } \\
\text { Response }\end{array}$} & \multicolumn{4}{|c|}{$\begin{array}{l}\text { Increase of Daily Urine Volume and Elec- } \\
\text { trolyte Excretion on Day of Maximum } \\
\text { Response, in Comparison with Control }\end{array}$} & \multirow{2}{*}{$\begin{array}{c}\text { Therapeutic } \\
\text { Result }\end{array}$} \\
\hline & & & & & & & & $\begin{array}{c}\text { Urine Vol. } \\
\text { (1.) }\end{array}$ & $\underset{(\mathrm{mEq})}{\text { Sodium }}$ & $\begin{array}{l}\text { Potassium } \\
\text { (mEq) }\end{array}$ & $\begin{array}{l}\text { Chloride } \\
\text { (mEq) }\end{array}$ & \\
\hline $\begin{array}{l}1 \\
2 \\
3 \\
4 \\
5 \\
6 \\
7 \\
7\end{array}$ & $\begin{array}{l}\mathbf{M} \\
\mathbf{M} \\
\mathbf{F} \\
\mathbf{F} \\
\mathbf{M} \\
\mathbf{M} \\
\mathbf{M} \\
\mathbf{F}\end{array}$ & $\begin{array}{l}54 \\
49 \\
60 \\
63 \\
58 \\
70 \\
58 \\
62\end{array}$ & $\begin{array}{l}\text { C.P. } \\
\text { C.P. } \\
\text { M.S. } \\
\text { H.H.D. } \\
\text { C.P. } \\
\text { A.I. } \\
\text { C.P. } \\
\text { C.P. }\end{array}$ & $\begin{array}{r}400-800 \\
400 \\
400 \\
600 \\
400-800 \\
800 \\
400-800 \\
400-800\end{array}$ & $\begin{array}{r}5 \\
5 \\
7 \\
6 \\
8 \\
4 \\
11 \\
6 .\end{array}$ & $\begin{array}{l}7 \cdot 2 \\
6 \cdot 9 \\
6 \cdot 5 \\
6 \cdot 5 \\
5 \cdot 1 \\
4 \cdot 0 \\
4 \cdot 4 \\
3 \cdot 4\end{array}$ & $\begin{array}{l}4 \\
4 \\
2 \\
2 \\
1 \\
2 \\
1 \\
5\end{array}$ & $\begin{array}{l}2.42 \\
3 \cdot 16 \\
2 \cdot 21 \\
2.40 \\
0.98 \\
1.34 \\
1.23 \\
1.67\end{array}$ & $\begin{array}{r}362 \\
255 \\
222 \\
306 \\
206 \\
175 \\
46 \\
126\end{array}$ & $\begin{array}{r}7 \\
24 \\
19 \\
27 \\
11 \\
34 \\
19 \\
-6\end{array}$ & $\begin{array}{r}322 \\
218 \\
192 \\
245 \\
237 \\
152 \\
49 \\
86\end{array}$ & $\begin{array}{l}\text { Good. Became free } \\
\text { from oedema }\end{array}$ \\
\hline $\begin{array}{r}9 \\
10 \\
11 \\
12 \\
13\end{array}$ & $\begin{array}{l}\mathbf{M} \\
\mathbf{F} \\
\mathbf{M} \\
\mathbf{M} \\
\mathbf{M}\end{array}$ & $\begin{array}{l}54 \\
53 \\
67 \\
75 \\
63\end{array}$ & $\begin{array}{l}\text { C.P. } \\
\text { H.H.D. } \\
\text { C.P. } \\
\text { H.H.D. } \\
\text { M.S. }\end{array}$ & $\begin{array}{r}600-800 \\
400 \\
400 \\
400-800 \\
600\end{array}$ & $\begin{array}{r}5 \\
5 \\
7 \\
4 \\
-5\end{array}$ & $\begin{array}{l}4 \cdot 5 \\
3 \cdot 9 \\
3 \cdot 7 \\
2 \cdot 1 \\
1 \cdot 7\end{array}$ & $\begin{array}{l}2 \\
2 \\
3 \\
2 \\
4\end{array}$ & $\begin{array}{l}2.35 \\
1.55 \\
1.50 \\
1.02 \\
1.55\end{array}$ & $\begin{array}{r}329 \\
76 \\
42 \\
59 \\
78\end{array}$ & $\begin{array}{r}15 \\
14 \\
43 \\
4 \\
70\end{array}$ & $\begin{array}{r}254 \\
34 \\
40 \\
69 \\
22\end{array}$ & $\left\{\begin{array}{l}\text { Fair. Remained } \\
\text { slightly oedema- } \\
\text { tous }\end{array}\right.$ \\
\hline $\begin{array}{l}14 \\
15 \\
16 \\
17\end{array}$ & $\begin{array}{l}\mathbf{F} \\
\mathbf{M} \\
\mathbf{F} \\
\mathbf{F}\end{array}$ & $\begin{array}{l}49 \\
52 \\
55 \\
44\end{array}$ & $\begin{array}{l}\text { M.S. } \\
\text { C.P. } \\
\text { C.P. } \\
\text { M.S. }\end{array}$ & $\begin{array}{r}400-800 \\
400 \\
400-800 \\
400\end{array}$ & $\begin{array}{l}4 \\
3 \\
3 \\
2\end{array}$ & $\begin{array}{l}1.3 \\
1 \cdot 3 \\
1 \cdot 1 \\
0.5\end{array}$ & $\begin{array}{l}1 \\
3 \\
1 \\
1\end{array}$ & $\begin{array}{l}0.13 \\
1.32 \\
0.32 \\
0.45\end{array}$ & $\begin{array}{r}56 \\
175 \\
12 \\
8\end{array}$ & $\begin{array}{r}28 \\
4 \\
13 \\
0\end{array}$ & $\begin{array}{r}88 \\
110 \\
36 \\
19\end{array}$ & $\left\{\begin{array}{l}\text { Poor. Little change } \\
\text { in oedema }\end{array}\right.$ \\
\hline
\end{tabular}

C.P. $=$ Cor pulmonale. M.S. $=$ Mitral stenosis. H.H.D. $=$ Hypertensive heart disease. A.I. $=$ Aortic incompetence.

in these 13 patients. These data are not intended to provide an accurate comparison of the effects of aminometradine and mersalyl; the number of patients is small, and the two drugs were not given under identical conditions in each individual, a state which it is frequently impossible to achieve. The general trend of the results indicates, however, that during the first 24 hours after administration $2 \mathrm{ml}$. of a mercurial diuretic exerts a larger effect on water and salt excretion than $400-800 \mathrm{mg}$. of aminometradine.

T'wo points of difference between the effects of aminometradine and mersalyl may be noted : (1) On average each litre of urine excreted in excess of the "control" (pretreatment) rate during administration of aminometradine accompanied an increase of $96 \mathrm{mEq}$ of sodium ion and $81 \mathrm{mEq}$ of chloride ion. On the other hand, each litre of urine excreted in excess as a result of mersalyl therapy accompanied $107 \mathrm{mEq}$ of sodium and a slightly larger quantity of chloride ion $(117 \mathrm{mEq})$. (2) A good diuresis may, in many patients, be obtained during the second 24 hours after the last dose of aminometradine (Fig. 1), whereas a "rebound" reduction of urine flow is often observed in the second 24 hours after an injection of mersalyl (Fig. 3).

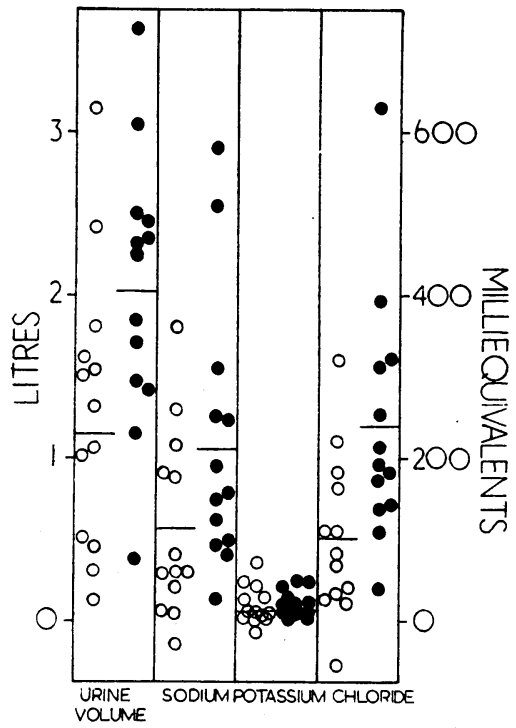

Toxic Effects.-During administration of aminometradine, three patients developed nausea and vomiting of sufficient severity to necessitate withdrawal of the drug. On e patient developed mild diarrhoea and one other had epigastric pain. The doses employed - in these five persons were 400 to 800 mg. daily. No other ill effects were encountered.

\section{Discussion}

Little is known of the mechanism of action of aminometradine beyond the fact that it increases the urinary excretion of aminometradine and mersalyl resp tively in 13 patients. Horizontal lines indicate mean values for each group. sodium and chloride without causing any increase in glomerular filtration rate. It therefore presumably inhibits reabsorption of sodium and chloride by the renal tubules (Kattus et al. 1952), and it seems probable that the increased urine flow is an osmotic diuresis occasioned by increased salt excretion. The present observations indicate that the diuresis caused by $400 \mathrm{mg}$. of aminometradine is, on average, materially less than that which results from an intramuscular injection of $2 \mathrm{ml}$. of mersalyl, but that aminometradine was nevertheless a satisfactory diuretic in approximately half of our patients with congestive heart failure, and has" the advantage of being effective whe $n$ taken orally. These conclusions on the therapeutic effect of amino-

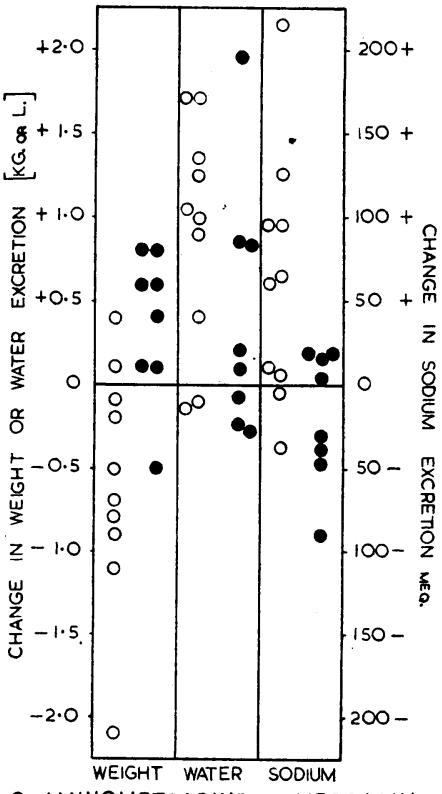

- AMINOMETRADINE MERSALYL

FIG. 3.-Urine flow and excretion of electrolytes in the second 24aminometradine or mersalyl (changes with respect to the control period). hour period after the last dose of

metradine agree with the results of Kattus et al. (1952), who employed SC 2614. The results of Imburgia (1952), who administered larger doses of aminometradine, were more favourable, but the present results do not suggest that any benefit will be gained by increasing the dose of aminometradine from 400 to $800 \mathrm{mg}$. daily, and the likelihood of nausea and vomiting is increased.

It seems improbable that amipometradine will supplant the well-established effect of mercurial diuretics in the treatment of severe congestive heart failure, but the drug may have a useful place in the treatment of less severe cases where an immediate diuresis is not imperative. So far as we are aware there have been no published observations on whether aminometradine is likely to prove effective in the difficult therapeutic problem of "resistance" to mercurials, and the present results bear only indirectly on this question. It has been shown by Schwartz and Wallace (1950) that " resistance" to mercurial diuretics is due, in some instances, to reduction of the plasma chloride concentration, and the 
general similarity between the renal effects of aminometradine and of mersalyl suggests that the same mechanism of "resistance" might apply to both drugs. As shown in these results, the increase of chloride excretion exceeded that of sodium after mersalyl but was slightly less than the increase of sodium excretion in the case of aminometradine. This will lessen somewhat the liability of aminometradine to reduce the plasma chloride concentration and also render the development of "resistance" to this drug less probable.

Although the effect of mersalyl was greater than that of aminometradine during the first 24 hours after administration of either drug, the urine flow during the second 24 hours was frequently greater after aminometradine. Thus the net effect of the two drugs when they were administered at intervals of $\mathbf{4 8}$ hours was comparable. The more sustained and less violent diuresis caused by aminometradine given every 24 or 48 hours, as compared with that produced by mercurial diuretics, which are usually administered two or three times weekly, may be advantageous in some patients with heart failure.

The observations that the maximum diuresis from aminometradine often does not develop until the third or fourth day of administration, and that the diuresis caused by a single dose lasts more than 24 hours, suggests that a single dose of $400 \mathrm{mg}$. is not completely excreted in 24 hours. It is therefore probably advisable not to administer the drug daily but to allow one or two days of freedom from treatment each week.

It is possible that the main use of aminometradine may be found in the prophylaxis of oedema in those patients with chronically recurring cardiac failure who constantly require a diuretic. As pointed out by Spencer and Lloyd-Thomas (1953), assessment of the diuretic action of any drug in the treatment of heart failure is fraught with difficulty, owing largely to the tendency of the patients' clinical condition to fluctuate spontaneously, and this applies particularly to the prophylaxis of cardiac oedema. The evidence accumulated so far suggests, however, that a clinical trial of the prophylactic effect of aminometradine would be worth undertaking.

\section{Summary}

The effect of the oral diuretic aminometradine (mictine) on the urine flow and electrolyte excretion of 20 patients with congestive heart failure has been studied.

The increase of urine flow and the augmented excretion of sodium and chloride which resulted from 400 to $800 \mathrm{mg}$. of aminometradine were, in general, somewhat less than those caused by $2 \mathrm{ml}$. of mersalyl.

The drug produced a good therapeutic effect in eight patients, in five the response was fairly good, and in five it was negligible.

Aminometradine is regarded as a fairly effective agent in the treatment of congestive heart failure where an immediate diuresis is not urgently required.

Toxic effects were confined to the gastro-intestinal tract. In three patients the drug was discontinued owing to nausea and vomiting. Little advantage is gained by increasing the dose beyond $400 \mathrm{mg}$. daily in the majority of patients.

We are grateful to Professor C. H. Stuart-Harris for advice and encouragement, and to Dr. James W. Brown for permission to treat a number of patients under his care in the Sheffield Regional Cardiovascular Centre. We are also indebted to Mrs. M. Bell and Mr. R. Saynor for valuable technical assistance.

\section{REFERENCES}

Hanley, T., and Platts, M. M. (1956). J. clin. Invest., 35, 20. Imburgia, R. (1952). Proc. Rochester (N.Y.) Gen. Hosp., 4, 106 Kattus, A. A., Arrington, T. M., and Newman, E. V. (1952). Amer. J. Med., 12, 319

Papesch, V.P and Schroeder, E. F. (1951), J. org. Chem., 16, 1879. Spencer, ${ }^{\prime}$ G., and Lloyd-Thomas, $\mathbf{H}$. (1950). clin. Invest., 29, 844. 1. 957 .

\section{SHIGELLOSIS IN THE FIRST TWO YEARS OF LIFE}

BY

\section{BORIS MRAVUNAC, M.D.}

\author{
AND \\ DANICA WEBER, M.D. \\ From the Hospital for Infectious Diseases, Zagreb, \\ Yugoslavia
}

In infancy the classical picture of bacillary dysentery is often absent and the patient may present a variety of clinical patterns, and, moreover, in this age group the characteristic features of dysentery may be produced by other agents, infective or non-infective. In Yugoslavia, about 5,000 cases of bacillary dysentery are registered annually-a figure which is certainly far short of the actual total. The number of cases admitted in the first two years of life has steadily risen during recent years, among them many cases in infants, who are particularly susceptible to such infection. The variety

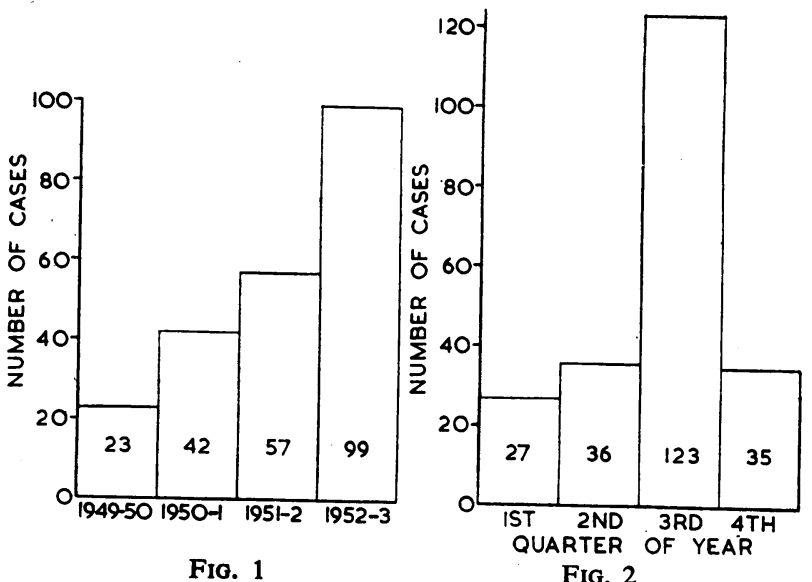
FIG. 1.-Yearly distribution (June 1-May 31) of bacillary dysen-
tery. FIG. 2.- Seasonal distribution of bacillary dysentery (1949-53).

TABle I.-Age Distribution of Cases of Shigella Infection

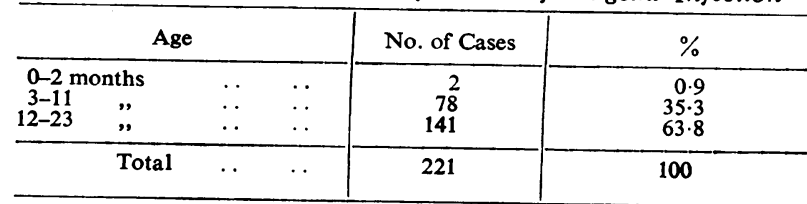

of clinical pictures which can occur has led us to analyse our experience with such cases admitted to the Infectious Diseases Hospital in Zagreb between June, 1949, and May, 1953.

The distribution of the cases by year and by season is shown in Figs. 1 and 2. The latter illustrates the fact, already well known, that shigellosis is a disease of warm seasons. Table I gives the age distribution of the 221 cases included in our series and shows that the highest proportion of cases was in the second year of life. The majority of patients (158) came from the town of Zagreb; the remainder were from the surrounding country districts.

\section{Bacteriological Examinations}

Specimens of fresh faeces or rectal swabs were taken in every case, and were plated immediately on SS agar at the patient's bedside. At least two specimens were examined before treatment was started. Despite this rather intensive 